\title{
An Optimal Prediction Model's Credit Risk: The Implementation of the Backward Elimination and Forward Regression Method
}

\author{
Sara HALOUI ${ }^{1}$ \\ $\mathrm{PhD}$ - Student \\ ENCG Kenitra, Ibn Tofail University -Kenitra, MOROCCO \\ Research Laboratory: Management Sciences of \\ Organizations
}

\author{
Abdeslam El MOUDDEN ${ }^{2}$ \\ Research- Professor \\ ENCG Kenitra, Ibn Tofail University -Kenitra, MOROCCO \\ Research Laboratory: Management Sciences of \\ Organizations
}

\begin{abstract}
The purpose of this paper is to verify whether there is a relationship between credit risk, main threat to the banks, and the demographic, marital, cultural and socio-economic characteristics of a sample of $\mathbf{4 0}$ credit applicants, by using the optimal backward elimination model and the forward regression method. Following the statistical modeling, the final result allows us to know the variables that have a degree of significance lower than 5\%, and therefore a significant relationship with the credit risk, namely the CSP (Socio-occupational category), the amount of credit requested, the repayment term and the type of credit. However, by implementing the second method, the place of residence variable was selected as an impacting variable for the chosen model. Overall, these features will help us better predict the risk of bank credit.
\end{abstract}

Keywords-Credit risk; prediction; optimal model; backward elimination; statistical modeling

\section{INTRODUCTION}

Generally in the banking environment, among a variety of risks to which a bank may be exposed, credit risk remains the biggest and most dangerous, its control and evaluation are essential steps to continually improve the performance of banks in the financial market [1]. This necessarily involves the implementation of instruments and devices to anticipate and predict this type of risk. In this sense, setting up credible mechanisms of banking risk management to ensure the stability of the international banking system, was the main goal behind the enactment of prudential rules, commonly referred to as the Basel Accords, which are generally applicable to all banks with significant international activity [2]. For the bank, the credit risk management is therefore a matter of survival. Moreover, logistic regression is the most widely used model in the development of credit scoring model [6].

In Morocco, the failure of banks' customers is increasing, since outstanding debts record the same upward trend every year, nevertheless no bank would resist at such conjunctures. Prior management of credit risk is fundamental since it takes into account the assessment and prevention of this risk.

In this article, we want to show the significant link between credit risk and the socio-economic, marital, cultural and demographic variables of the credit applicants. We would like to point out that the central issue to which we are trying to provide empirical answers is the following: "How can the prediction of bank credit risk be improved?"

To answer the problematic of our research, we will review generalities about credit risk, overview of the inventory of outstanding debts in Morocco would also be necessary in our research, and we will of course discuss prudential and banking regulation as the international banking environment is governed by the Basel agreements, essentially the bank credit component. In the end, this paper will use a statistical model to predict the risk of bank credit.

\section{LITERATURE REVIEW}

\section{A. Credit Risk : A General View}

1) The conceptual framework: As soon as an economic agent gives credit to counterparty, a risk relationship is established between the creditor and his debtor, the latter can indeed, with good or bad faith, do not pay his debt on the agreed date. The risk of meeting a commitment to settle a debt is the credit risk [13]. Hence, the credit transaction might create the risk that a debtor cannot honor its commitments [15].

According to the Bank of International Settlements (2011) [5], the credit risk lies in the fact that the counterparty may not fulfill its obligations according to the agreed upon contractual conditions. A financial asset is considered unpaid when a counterparty has not made the payment due at the contractual maturity.

It can also manifest itself in counterparty defaults, failures in commitments or concentration of bad debts. In general, credit risk is a particular risk from a lending transaction, and the occurrence of a negative event affects the debt on which the debtor is engaged. It is one of the main causes of bank failure.

2) Credit risk assessment: To mitigate credit risk, it is highly recommended for banks to assess repayment capacity and guarantees, to select operations taking into account profitability and costs (financing, operational, cost of risk, return on equity), take into account the economic and legal 
environment, and finally monitor bad debts and provisioning [11].

Banks have to set up a credit policy framed by a committee of commitments which sets the objectives (type of clientele, of credit, sectors and geographical areas), credit terms (rates, margins, guarantees) and delegations of power. The credit processing procedures go through the study of the demand (taking of information and evaluation of solvency), monitoring (detection of the risk of insolvency) and internal control of counterparty risk. The bank has real expertise in assessing the counterparty risk of individuals (consumer loans or mortgages) or companies (loans financing cash or investment) [14]. However, it is necessary to point out that it is common to use the term counterparty risk to refer exclusively to the credit risk while this is not the case.

\section{B. Credit Risk and Basel Agreements}

The bank is one of the most regulated economic sectors in the world. Otherwise, the State of the banking sector is indicative for the condition of the entire financial market and, by extension, of the entire economy [16]. To prevent the scale of banking crises, control devices have been introduced, mainly by Basel Committee. Their purpose is to help retail and investment banks control their credit or market risks through a prudential approach that combines risk measurement with a minimum equity allocation [14].

Cieply (2018) [7] concluded that the purpose of prudential regulation is to reduce the probability of bankruptcy of banks. For this, in their normal business, banks are required to meet management standards. They aim is to contain each of the major risks to which banks are exposed, particularly the risk of illiquidity and insolvency.

So, each of the three Basel agreements entails regulatory constraints imposed on the banking institutions that they are expected to respect, in order to maintain their financial stability.

1) Basel accord I: The Basel accord I, created in 1988, sets up a system to better control the measurement of credit risks. A minimum ratio of $8 \%$ is then imposed between a capital of a bank and the risks it bears on the market or the credit risks it takes with its customers [9].

This regulatory constraint is in the form of a ratio called Cooke which, according to Cieply (2018) [7], require credit institutions to constantly comply with a ratio of at least $8 \%$ between their own funds and the commitments of credit weighted against their risk. The weighting was based in Basel I on the nature of the counterparty by following a purely institutional criterion.

2) Basel accord II: Dhafer and Cesbron (2012) [9] argue that in the face of a financial system that has become more complex, in particular because of the growing importance of globalization, the Basel Committee strengthened its regulation. The new device is based on three pillars: 1st pillar - the capital requirement with a ratio of $8 \%$, 2nd pillar - the establishment of a more comprehensive prudential supervisor procedure with, inter alia, the introduction of an internal risk management model, 3rd pillar - the need for better, transparent and uniform communication, which strengthens market discipline.

3) According to dhafer (2012) [8], the purpose of pillar II is twofold: On the one hand, to encourage banks to develop techniques for managing their risks and their level of capital and, on the other hand, to enable regulators to increase regulatory capital requirements if necessary. This need must be applied in two ways:

- Stress testing: Banks must prove during simulations of extreme situations, the validity of its own funds in case of economic crisis.

- Back testing: The banks must prove the validity of their statistical methods over quite long periods (5 to 7 years).

4) Basel accord III reinforcement of the basel II system: In 2010, the Basel Committee published the Basel Accord III in order to meet the Basel II limits and to prevent future crises [12].

In the same context, Dhafer and Cesbron [9] argue that following the 2008 crisis, the Basel Committee reacted and took a number of steps to strengthen the "resilience" of the banking sector. It is then a matter of consolidating the solvency of banks, to develop a greater liquidity monitoring, to improve the ability of banks to absorb shocks, resulting from financial and economic stress, and finally reduce and control the risks of overflow to the real economy.

These agreements focus on four points that are: the redefinition of own funds, the establishment of a precautionary capital or mattress and counter-cyclical measures, setting up ratios and covering certain risks [17].

\section{Statement of Outstanding Debts of Banks in Morocco}

In recent years, Moroccan banks have turned to the household segment to boost credit activity. However, the interest in this category is not without its repercussions: the aggravation and rapid evolution of the outstanding debts of individuals is one of the remarkable effects.

The monetary statistics provided by Bank Al-Maghrib under its report on financial stability (2018) [3] revealed as described in Fig. 1 that at the end of 2018 the outstanding debts recorded an increase of $3.7 \%$ against $2.3 \%$ a year earlier to reach 65.3 billion dirhams. This increase primarily concerns loans granted to households, which is more than 2.7 billion dirhams compared to 2017. On the other hand, the outstanding debts of companies fell by $1 \%$. Moderately, the rate of outstanding debts posted is $7.3 \%$ against respectively $7.5 \%$ and $7.6 \%$ in 2017 and 2016.

According to the latest figures published by the BAM 2019 [4], at the end of June 2019, Table I shows that households are left with almost 27.5 billion DH of arrears at banks, given that the outstanding receivables total an amount of 67.7 billion dirhams and represent $7.5 \%$ of the total loans outstanding for the same period. 
TABLE. I. BREAKDOWN OF BANK CREDIT AND OUTSTANDING DEBTS

\begin{tabular}{|c|c|c|c|c|c|c|c|c|}
\hline & \multirow{2}{*}{$\begin{array}{l}\text { Outstanding at } \\
\text { the end of June } \\
2019^{*}\end{array}$} & \multirow{2}{*}{$\begin{array}{l}\text { Monthly } \\
\text { variation (in } \\
\% \text { ) }\end{array}$} & \multicolumn{6}{|c|}{ Annual growth rate (in \%) } \\
\hline & & & June18 & Sept.18 & Dec.18 & March19 & May19 & June19 \\
\hline Bank credit & 900,4 & 3,5 & 1,8 & 2,9 & 3,2 & 5,1 & 4,4 & 5,1 \\
\hline Households credit & 338,2 & $-0,2$ & 3,7 & 4,9 & 5,3 & 5,7 & 5,8 & 5,4 \\
\hline Consumer credits & 55 & 0,1 & 5,7 & 6,0 & 6,2 & 6,0 & 4,9 & 4,1 \\
\hline Real estate loans & 219,1 & $-0,2$ & 4,8 & 4,6 & 6,0 & 5,2 & 5,0 & 3,8 \\
\hline Housing loans & 211,6 & $-0,1$ & 4,3 & 4,6 & 5,7 & 5,6 & 5,7 & 4,9 \\
\hline Loans to real estate developers & 6,8 & $-4,1$ & 16,1 & 10,3 & 16,2 & $-2,3$ & $-12,4$ & $-19,8$ \\
\hline Outstanding debts & 67,7 & 0 & 2,9 & 3,4 & 2,5 & 5,5 & 3,7 & 5,7 \\
\hline Private non-financial corporations & 39,5 & 1,9 & 3,9 & 3,2 & 2,5 & 0,7 & 0,1 & 2,8 \\
\hline Households & 27,5 & $-1,9$ & 1,2 & 3,9 & 2,7 & 13,7 & 11,3 & 11,3 \\
\hline Ratio of outstanding debts & & & 7,5 & 7,7 & 7,5 & 7,7 & 7,8 & 7,5 \\
\hline *In billions of DH & & & & & & & & \\
\hline
\end{tabular}

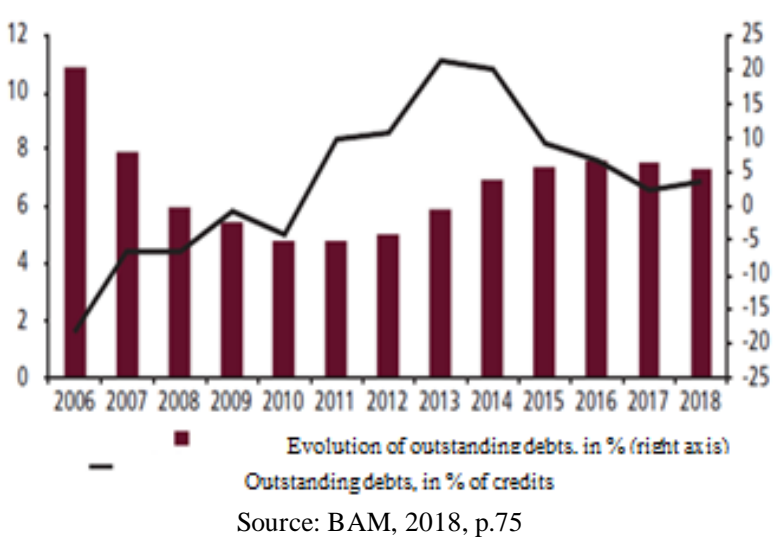

Fig. 1. Evolution of Outstanding Debts of Banks.

The results recorded in relation to the situation of outstanding debts born by Moroccan banks, invite us to shed light on these findings, to think in a thorough way, and to further develop appropriate tools and mechanisms to assess this risk that could put banks in critical conditions.

\section{MODELING OF CREDIT RISK}

\section{A. Work Methodology}

Our empirical approach imposes the adoption of a methodology that is based on sampling, data analysis. These empirical results will be presented in statistical tables with their interpretations.

1) Sampling: To find the optimal model, we took a sample of 40 credit applicants using the simple random sampling method to estimate and predict credit risk through the backward elimination and forward regression method. The data is collected through the questionnaire method distributed to 40 respondents who are credit applicants. We choose these two statistical methods in order to search the optimal model in our scientific research.

Table II presents the composition of the sample of defaulting and non-defaulting customers.
TABLE. II. BREAKDOWN OF DEFAULTING AND NON-DEFAULTING CUSTOMERS IN THE SAMPLE

\begin{tabular}{|l|l|l|}
\hline & Sample & Percentage \\
\hline Defaulting customer & 13 & $\mathbf{3 2 . 5 \%}$ \\
\hline Non-defaulting customer & 27 & $\mathbf{6 7 . 5 \%}$ \\
\hline Total & $\mathbf{4 0}$ & $\mathbf{1 0 0 \%}$ \\
\hline
\end{tabular}

2) Characteristics of the sample: The independent variables retained with their modalities for the analysis of the data are declined below:

- Age: The age of the customer [Under 30years, 30 to 39 years, 40 to 49 years, 50 years and over].

- Gender: The gender of the client [Man, Woman].

- Etatmatri: The marital status of client [Single, Married, Divorced, Widower].

- Milieuderés: The place of residence of client [Urban, Rural].

- Zonegéo: The geographical area where the customer lives [Casablanca-Settat, Rabat-Salé-Kénitra, FèsMeknès, Marrakech-Asfi, Tanger-Tétouan-Alhoceima, Oriental, others].

- CSP: The socio-occupational category ofthe client [Employee of a small company, employee of a large company, civil servant, tradesman and entrepreneur, liberal professions].

- Income (Revenu): The income received by the client [less than $4000 \mathrm{dh}$, from 4000 to $6000 \mathrm{dh}$, from 6000 to $10000 \mathrm{dh}$, Greater than $10000 \mathrm{dh}]$.

- Nbredoscréd: The number of credit files available to the client $[0,1,2,3]$.

- Montcrédsolli: The amount of credit requested [5000 to $10000 \mathrm{dh}, 10000$ to $20000 \mathrm{dh}, 20000$ to $50000 \mathrm{dh}, 50000$ to $100000 \mathrm{dh}, 100000$ and over]. 
- Duréerem: The repayment term of the credit [12months, 12-36months, 36-60months, more than 60months].

- Typecrédit: The type of credit desired [Consumer credit, Real estate credit].

- Degrérat: The difference between the amount requested and the amount awarded $[=0,>0]$.

3) Descriptive statistics: First, we present the descriptive statistics relating to the explanatory variables in Table III as follow:

From the statistics above associated with the explanatory variables, we can observe a strong dispersion of the observations.

4) Hypotheses to test: Two hypotheses are to be tested by statistical modeling [10]:

H1: There is a significant relationship between the credit risk and the demographic, marital, cultural and socioeconomic characteristics of credit applicants.

$\mathrm{H} 2$ : Some variables may be important and impacting in predicting credit risk.

5) The variables of the problem: The variable to be explained and the explanatory variables adopted for the treatment of the problematic posed above is given as:

$\mathrm{Y}=\mathrm{b}_{0}+\mathrm{b}_{1} \mathrm{X}_{1}+\cdots+\mathrm{b}_{\mathrm{k}} \mathrm{X}_{\mathrm{k}}+\varepsilon, \mathrm{k}=12$

$\mathrm{Y}=$ the variable to be explained (RISQCREDIT)

The explanatory variables:

$\mathrm{X}_{1}=$ the age of the client (Age)
$\mathrm{X}_{2}=$ the gender of the client (Sexe)

$\mathrm{X}_{3}=$ the marital status of the client (Etatmatrimonial)

$\mathrm{X}_{4}=$ the place of residence of the client (Milieuderés)

$\mathrm{X}_{5}=$ the geographical area where the client lives (Zonegéo)

$\mathrm{X}_{6}=$ the socio-occupational category of the client (CSP)

$\mathrm{X}_{7}=$ the income received by the client (Revenu)

$\mathrm{X}_{8}=$ the number of credit files available to the client (Nbredoscréd)

$\mathrm{X}_{9}=$ the amount of credit requested (Montcrédsolli)

$\mathrm{X}_{10}=$ the repayment term of the credit (Duréerem)

$\mathrm{X}_{11}=$ the type of credit desired (Typecrédit)

$\mathrm{X}_{12}=$ the difference between the amount requested and the amount awarded (Degrérat)

$\boldsymbol{b}_{\boldsymbol{i}}=$ Coefficients representing the linear combination of the predictor and the constant

$\varepsilon=$ The error

The dependent variable is credit risk. It is a dichotomous binary variable denoted "RISQCREDIT" such as:

RISQCREDIT $=0$ if the client is solvent and repay his credits at maturity.

RISQCREDIT $=1$ if the client is insolvent and will not repay his credits at maturity.

This makes it possible to highlight the degree of significance of the independent variables with respect to the dependent variable.

TABLE. III. EXPLANATORY VARIABLES

\begin{tabular}{|c|c|c|c|c|c|c|c|c|c|}
\hline $\begin{array}{l}\text { Explanatory } \\
\text { variables }\end{array}$ & Mean & Median & $\operatorname{Max}$ & Min & Std. dev & Skewness & Kurtosis & Jarque-Bera & probability \\
\hline Age & 1.325 & 1.000 & 3.000 & 0.000 & 1.071484 & 0.210487 & 1.819931 & 2.616306 & 0.270319 \\
\hline Gender & 0.450 & 0.000 & 1.000 & 0.000 & 0.503831 & 0.201008 & 1.040404 & 6.669387 & 0.035625 \\
\hline Marital Status & 0.950 & 1.000 & 3.000 & 0.000 & 0.845804 & 0.866483 & 3.474737 & 5.380910 & 0.067850 \\
\hline Place of residence & 0.250 & 0.000 & 1.000 & 0.000 & 0.438529 & 1.154701 & 2.333333 & 9.629630 & 0.008109 \\
\hline Geographical area & 1.225 & 1.000 & 5.000 & 0.000 & 1.310461 & 1.238532 & 3.851849 & 11.43583 & 0.003287 \\
\hline Socio-occupational Category & 1.775 & 2.000 & 4.000 & 0.000 & 1.270726 & 0.202029 & 2.179973 & 1.392843 & 0.498365 \\
\hline Income & 1.750 & 2.000 & 3.000 & 0.000 & 1.031553 & -0.195169 & 1.858760 & 2.424654 & 0.297504 \\
\hline Number of Credit files & 0.575 & 0.000 & 3.000 & 0.000 & 0.747217 & 1.234518 & 4.202353 & 12.56966 & 0.001864 \\
\hline Amount of credit requested & 2.625 & 3.000 & 4.000 & 0.000 & 1.314368 & -0.790170 & 2.605819 & 4.421424 & 0.109623 \\
\hline Repayment term of credit & 2.325 & 3.000 & 3.000 & 0.000 & 0.828576 & -0.934844 & 2.912953 & 5.838853 & 0.053965 \\
\hline The type of credit & 0.250 & 0.000 & 1.000 & 0.000 & 0.438529 & 1.154701 & 2.333333 & 9.629630 & 0.008109 \\
\hline The degree of rationing & 0.325 & 0.000 & 1.000 & 0.000 & 0.474342 & 0.747265 & 1.558405 & 7.186359 & 0.027511 \\
\hline
\end{tabular}




\section{B. Empirical Results}

1) The selection of the optimal model: Now, we proceed to the tests of the choice of the most significant explanatory variables in relation to the variable to be explained, and we will do this through the method of elimination of nonsignificant variables at the threshold of $5 \%$ one by one in order to make a successive correction of the proposed model. In this context, we use the backward elimination method and the forward regression.

- The Backward Elimination method

The initial model adopted using the different variables that is supposed to be explanatory is given as follows in Table IV:

- Income variable is the least significant. We eliminate it and we continue to re-estimate the equation. The new model then takes the new form (Annex 1).

- The variable to be eliminated this time is the marital status variable. Then the new model is obtained in Annex 2.

- Then, we eliminate the variable AGE. Hence the new model is in Annex 3.
- The variable to be eliminated now is the number of credit files available to the client (NBREDOSCRED). And the re-estimated model obtained in Annex 4.

- Then, the variable associated to the place of residence (MILIEUDERES) is eliminated. The new model takes the new form in Annex 5.

- And this time, the variable to eliminate is Gender. The new model (Annex 6) takes the new form.

- Then, we eliminate the variable associated with the degree of rationing (DEGRERAT) which means the difference between the amount requested and the amount awarded. And the re-estimated model becomes as indicated in Annex 7.

- And then the variable associated with the geographical area (ZONEGEO) is eliminated. Hence, the following and the last model adopted is given in Table V:

In this new final model, the remaining variables, CSP, MONTCREDSOLLI, DUREEREM, and TYPECREDIT are significant at the threshold of $\alpha=5 \%$. This is the optimal model obtained by the backward regression method.

TABLE. IV. THE INITIAL MOdEL AdOPTED

\begin{tabular}{|c|c|c|c|c|}
\hline \multicolumn{5}{|c|}{ Dependent Variable: RISQCREDIT } \\
\hline \multicolumn{5}{|l|}{ Method: Least Squares } \\
\hline \multicolumn{5}{|c|}{ Date: $07 / 29 / 19$ Time: $21: 01$} \\
\hline \multicolumn{5}{|l|}{ Sample: 140} \\
\hline \multicolumn{5}{|l|}{ Included observations: 40} \\
\hline Variable & Coefficient & Std. Error & t-Statistic & Prob. \\
\hline AGE & 0.018147 & 0.092667 & 0.195827 & 0.8462 \\
\hline SEXE & 0.114491 & 0.160077 & 0.715222 & 0.4804 \\
\hline ETATMATRIMONIAL & 0.014819 & 0.107447 & 0.137916 & 0.8913 \\
\hline MILIEUDERES & 0.112921 & 0.206375 & 0.547163 & 0.5886 \\
\hline ZONEGEO & 0.063002 & 0.060039 & 1.049345 & 0.3030 \\
\hline CSP & 0.088344 & 0.065254 & 1.353843 & 0.1866 \\
\hline REVENU & 0.011269 & 0.143172 & 0.078711 & 0.9378 \\
\hline NBREDOSCRED & -0.046702 & 0.137017 & -0.340850 & 0.7358 \\
\hline MONTCREDSOLLI & -0.281958 & 0.153218 & -1.840240 & 0.0764 \\
\hline DUREEREM & 0.215460 & 0.145782 & 1.477959 & 0.1506 \\
\hline TYPECREDIT & 0.410711 & 0.249898 & 1.643511 & 0.1115 \\
\hline DEGRERAT & 0.213677 & 0.208225 & 1.026186 & 0.3136 \\
\hline R-squared & 0.324790 & \multicolumn{2}{|c|}{ Mean dependent var } & 0.325000 \\
\hline Adjusted R-squared & 0.059529 & \multicolumn{2}{|c|}{ S.D. dependent var } & 0.474342 \\
\hline S.E. of regression & 0.460007 & \multicolumn{2}{|c|}{ Akaike info criterion } & 1.528173 \\
\hline Sumsquaredresid & 5.924969 & \multicolumn{2}{|c|}{ Schwarz criterion } & 2.034837 \\
\hline Log likelihood & -18.56346 & \multicolumn{2}{|c|}{ Hannan-Quinn criter. } & 1.711367 \\
\hline Durbin-Watson stat & 1.881081 & & & \\
\hline
\end{tabular}


TABLE. V. THE LAST ModEl AdOPTED

\begin{tabular}{|c|c|c|c|c|}
\hline \multicolumn{5}{|c|}{ Dependent Variable: RISQCREDIT } \\
\hline \multicolumn{5}{|l|}{ Method: Least Squares } \\
\hline \multicolumn{5}{|c|}{ Date: 07/29/19 Time: $21: 47$} \\
\hline \multicolumn{5}{|l|}{ Sample: 140} \\
\hline \multicolumn{5}{|c|}{ Included observations: 40} \\
\hline Variable & Coefficient & Std. Error & $\mathrm{t}$-Statistic & Prob. \\
\hline CSP & 0.131344 & 0.050025 & 2.625593 & 0.0126 \\
\hline MONTCREDSOLLI & -0.364113 & 0.092067 & -3.954881 & 0.0003 \\
\hline DUREEREM & 0.374530 & 0.098955 & 3.784852 & 0.0006 \\
\hline TYPECREDIT & 0.462116 & 0.206267 & 2.240377 & 0.0313 \\
\hline R-squared & 0.216425 & \multicolumn{2}{|c|}{ Mean dependent var } & 0.325000 \\
\hline Adjusted R-squared & 0.151127 & \multicolumn{2}{|c|}{ S.D. dependent var } & 0.474342 \\
\hline S.E. of regression & 0.437031 & \multicolumn{2}{|c|}{ Akaike info criterion } & 1.277016 \\
\hline Sumsquaredresid & 6.875868 & \multicolumn{2}{|c|}{ Schwarz criterion } & 1.445903 \\
\hline Log likelihood & -21.54031 & \multicolumn{2}{|c|}{ Hannan-Quinn criter. } & 1.338080 \\
\hline Durbin-Watson stat & 1.836085 & & & \\
\hline
\end{tabular}

Source: These estimates were prepared using EViews

TABLE. VI. FORWARD REGRESSION METHOD

\begin{tabular}{|l|l|}
\hline & RISQCREDIT \\
\hline RISQCREDIT & 1.000000 \\
\hline AGE & -0.213150 \\
\hline SEXE & 0.230673 \\
\hline ETATMATRIMONIAL & -0.086280 \\
\hline MILIEUDERES & 0.338983 \\
\hline ZONEGEO & 0.085593 \\
\hline CSP & -0.003190 \\
\hline REVENU & -0.615730 \\
\hline NBREDOSCRED & -0.251392 \\
\hline MONTCREDSOLLI & -0.539792 \\
\hline DUREEREM & -0.340877 \\
\hline TYPECREDIT & -0.030817 \\
\hline DEGRERAT & 0.202279 \\
\hline
\end{tabular}

\section{- Forward Regression method}

The forward regression consists in selecting one by one the explanatory variables according to the highest correlation coefficient recorded with the variable to be explained.

Table VI presents the correlation coefficients connecting the dependent variable to the independent variables. The used method prompts us to use the highest correlation coefficient recorded with the credit risk $(\mathrm{Y})$.

The highest coefficient correlation we have selected is the variable place of residence (MILIEUDERES); we then check the meaning of the correlation coefficient:

$$
\hat{t}=\frac{0.338983}{\sqrt{\frac{1-0.338983}{40}}}=16.677
$$

Source: These estimates were prepared using EViews

Table VII gives us a new model with the variable selected.

Regarding the forward regression, the place of residence variable (MILIEUDERES), even if it was eliminated by the backward elimination method, since it is not significant at the $5 \%$ level, it was selected by forward regression since it scored the highest correlation with the variable to be explained. This occurred just after we assumed that the addition of this variable is significant, which means that it is significantly correlated with credit risk. 
TABLE. VII. The New Model with THE ExPlanatory VARIABLE SELECted

\begin{tabular}{|c|c|c|c|c|}
\hline \multicolumn{5}{|c|}{ DependentVariable: RISQCREDIT } \\
\hline \multicolumn{5}{|l|}{ Method: Least Squares } \\
\hline \multicolumn{5}{|c|}{ Date: $07 / 30 / 19$ Time: $20: 50$} \\
\hline \multicolumn{5}{|l|}{ Sample: 140} \\
\hline \multicolumn{5}{|c|}{ Includedobservations: 40} \\
\hline Variable & Coefficient & Std. Error & t-Statistic & Prob. \\
\hline $\mathrm{C}$ & 0.233333 & 0.082540 & 2.826909 & 0.0075 \\
\hline MILIEUDERES & 0.366667 & 0.165080 & 2.221143 & 0.0324 \\
\hline R-squared & 0.114910 & \multicolumn{2}{|c|}{ Meandependent var } & 0.325000 \\
\hline Adjusted R-squared & 0.091618 & \multicolumn{2}{|c|}{ S.D. dependent var } & 0.474342 \\
\hline S.E. of regression & 0.452091 & \multicolumn{2}{|c|}{ Akaike info criterion } & 1.298839 \\
\hline Sumsquaredresid & 7.766667 & \multicolumn{2}{|c|}{ Schwarz criterion } & 1.383283 \\
\hline Log likelihood & -23.97677 & \multicolumn{2}{|c|}{ Hannan-Quinn criter. } & 1.329371 \\
\hline F-statistic & 4.933476 & \multicolumn{2}{|c|}{ Durbin-Watson stat } & 1.770529 \\
\hline $\operatorname{Prob}(F-$-statistic $)$ & 0.032376 & & & \\
\hline
\end{tabular}

2) Analysis of results: Overall and according to tests done on Eviews, the obtained results showed that the explanatory variables, among the twelve variables are significant at the 5\% level, namely the CSP (socio-occupational category), the MONTCREDSOLLI (amount of credit requested), the DUREEREM (repayment period), and the TYPECREDIT (type of credit). This is based on the optimal model and the Backward Elimination, which consists of eliminating each non-significant explanatory variable. This means that the remaining variables, which are socio-economic characteristics related to the profile of each applicant for credit, have an influence on credit risk. More explicitly, these variables predict the default of credit applicants at maturity and can prove their impact on the probability of repaying debts or not. While the Forward Regression method gave us a new result, which is the variable "place of residence". We can therefore conclude that there is a significant relationship between credit risk and the socio-economic, marital, cultural and demographic characteristics of credit applicants, and that some independent variables can be impacting and predictive of credit risk, therefore, we confirm the two hypotheses (H1) and (H2) that have been tested and verified through modeling.

\section{CONCLUSION}

Credit risk is a particular risk that can be one of the main causes of bank failure in the event of actual occurrence. Thus, this article concludes that the two methods of statistical modeling (Backward Elimination and Forward Regression), carried out on Eviews, could lead to different results, and proposed new models.

The purpose of this research was to select the explanatory variables that predict the likelihood of credit risk for banks among credit applicants. To do this, two statistical methods are used to perform this modeling on a sample of 40 borrowers of bank credits.

The above results lead us to assume that it is difficult to bypass the credit risk in Morocco which represents the variable to explain in our case. However, it is important to note that the explanatory variables selected by the models, such as the type of credit, the repayment period, the sociooccupational category, the amount of credit requested and finally the place of residence, represent an influence tools on the probability of repayment of credits.

\section{REFERENCES}

[1] Ahmed, A., Seyoum, A., Kedir, H., \&Kedir, S. (2015). Credit Risk Management OfMfis Found In Ethiopia. European Scientific Journal, 11(31).

[2] Angima, C.B., Mwangi, M., Kaijage, E., \&Ogutu, M. (2017). Actuarial Risk Management Practices, Underwriting Risk and Performance of P \& C Insurance Firms in East Africa. European Scientific Journal. 13(22). doi: 10.19044/esj.2017.v13n22p207.

[3] Bank Al-Maghrib (2018). Rapport sur la stabilité financière, Number 6.

[4] BAM (2019). Revue mensuelle de la conjoncture économique, monétaire et financière. August.

[5] Bank of International Settlements (2011). " Réforme de la réglementation financière : Réalisations, risques et perspectives ", 81eAnnual Report, Bâle Suisse, June, 228p.

[6] Chen, H., \& Xiang, Y. (2017). The study of credit scoring model based on group lasso. Procedia computer science, 122, pp.677-684.

[7] Cieply, S. (2018). Quel avenir pour la relation banque-entreprise ?, Caen, EMS editions, 99p.

[8] Dhafer, S. (2012). L'impact de la réglementation de bale III sur les métiers des salariés des banques, étude thématique, Université Lille Nord de France, Septembre, 50p.

[9] Dhafer, S., \& Cesbron, C. (2012). L'impact de la réglementation de bale III sur les métiers des salariés des banques, thematicstudy, University Lille Nord de France et SKEMA et cabinet MEDIATION Observatoire des métiers, des qualifications et de l'égalité professionnelle entre les femmes et les hommes dans la banque, pp.20-23.

[10] Ghassan, H., \& Raiss, N., \& El-Moudden, A. (2008). Testing the Effect of the Land Tax on Tourism Investment.Munich Personal RePEc 
Archive (MPRA), n56384, pp.1-11. June. (Online at http://mpra.ub.unimuenchen.de/56384/).

[11] Greuning, H.,\&BrajovicBratanovic, S. (2004). Analyse et gestion du risque bancaire : Un cadre de référence pour l'évaluation de la gouvernance d'entreprise et du risque financier, 1ère édition, Paris, Editions ESKA.

[12] Hologne, A.-L. (2014). Le stress financier impacte-t-il les banques ? Cas de Belfius et d'Axa Bank Europe, Mémoire de recherche, Université catholique de Louvain, Louvain School of management, 126p.

[13] Kharoubi, C., \& Thomas, P. (2016). Analyse du risque de crédit : Banque \& Marchés, 2ème édition, Paris, RB édition, 164p.
[14] Pierandrei, L. (2015). Risk Management, Gestion des risques en entreprise, banque et assurance, Paris, Dunod, 320p. 2015.

[15] Siqani, S. H., \&Sekiraca, E. (2016). The Impact of the Internal Audit in Reducing Credit Risk in Commercial Banks in Kosovo. European Scientific Journal, 12(4). doi: 10.19044/esj.2016.v12n4p268.

[16] Sumna, P. (2013). Credit risk dynamics in Czech Republic. European Scientific Journal, 9(16).

[17] Yota, R. (2016). Le test de l'effet médiateur de la prise de risque et des effets modérateurs de la réglementation prudentielle et de la taille de la banque, Doctoral Thesis in Managment Sciences, supported on 12 Decembre 2016, University of Artois, 253p.

\section{ANNEXURES}

ANNEX. I. ELIMINATION OF THE VARIABLE INCOME AND THE RE-ESTIMATION OF THE EQUATION

\begin{tabular}{|c|c|c|c|c|}
\hline \multicolumn{5}{|c|}{ Dependent Variable: RISQCREDIT } \\
\hline \multicolumn{5}{|l|}{ Method: Least Squares } \\
\hline \multicolumn{5}{|c|}{ Date: $29 / 07 / 19$ Time: $21: 10$} \\
\hline \multicolumn{5}{|l|}{ Sample: 140} \\
\hline \multicolumn{5}{|l|}{ Included observations: 40} \\
\hline Variable & Coefficient & Std. Error & $\mathrm{t}$-Statistic & Prob. \\
\hline AGE & 0.018242 & 0.091057 & 0.200337 & 0.8426 \\
\hline SEXE & 0.116106 & 0.156013 & 0.744207 & 0.4627 \\
\hline ETATMATRIMONIAL & 0.016870 & 0.102438 & 0.164682 & 0.8703 \\
\hline MILIEUDERES & 0.111442 & 0.201966 & 0.551787 & 0.5853 \\
\hline ZONEGEO & 0.062670 & 0.058856 & 1.064805 & 0.2957 \\
\hline CSP & 0.089524 & 0.062408 & 1.434497 & 0.1621 \\
\hline NBREDOSCRED & -0.040635 & 0.111317 & -0.365034 & 0.7177 \\
\hline MONTCREDSOLLI & -0.274525 & 0.118566 & -2.315371 & 0.0279 \\
\hline DUREEREM & 0.213862 & 0.141866 & 1.507494 & 0.1425 \\
\hline TYPECREDIT & 0.404838 & 0.234376 & 1.727297 & 0.0948 \\
\hline DEGRERAT & 0.205480 & 0.177195 & 1.159626 & 0.2557 \\
\hline R-squared & 0.324640 & \multicolumn{2}{|c|}{ Meandependent var } & 0.325000 \\
\hline Adjusted R-squared & 0.091758 & \multicolumn{2}{|c|}{ S.D. dependent var } & 0.474342 \\
\hline S.E. of regression & 0.452056 & \multicolumn{2}{|c|}{ Akaike info criterion } & 1.478394 \\
\hline Sumsquaredresid & 5.926280 & \multicolumn{2}{|c|}{ Schwarz criterion } & 1.942836 \\
\hline Log likelihood & -18.56789 & \multicolumn{2}{|c|}{ Hannan-Quinn criter. } & 1.646322 \\
\hline Durbin-Watson stat & 1.879857 & & & \\
\hline
\end{tabular}


ANNEX. II. ELIMINATION OF THE VARIABLE MARITAL STATUS AND THE RE-ESTIMATION OF THE EQUATION

\begin{tabular}{|c|c|c|c|c|}
\hline \multicolumn{5}{|c|}{ DependentVariable: RISQCREDIT } \\
\hline \multicolumn{5}{|l|}{ Method: Least Squares } \\
\hline \multicolumn{5}{|c|}{ Date: $07 / 29 / 19$ Time: $21: 16$} \\
\hline \multicolumn{5}{|l|}{ Sample: 140} \\
\hline \multicolumn{5}{|c|}{ Included observations: 40} \\
\hline Variable & Coefficient & Std. Error & t-Statistic & Prob. \\
\hline AGE & 0.024276 & 0.081999 & 0.296049 & 0.7692 \\
\hline SEXE & 0.116249 & 0.153460 & 0.757520 & 0.4546 \\
\hline MILIEUDERES & 0.111904 & 0.198645 & 0.563335 & 0.5774 \\
\hline ZONEGEO & 0.060792 & 0.056797 & 1.070345 & 0.2930 \\
\hline CSP & 0.091816 & 0.059843 & 1.534282 & 0.1354 \\
\hline NBREDOSCRED & -0.039854 & 0.109398 & -0.364304 & 0.7182 \\
\hline MONTCREDSOLLI & -0.275347 & 0.116524 & -2.362996 & 0.0248 \\
\hline DUREEREM & 0.216841 & 0.138408 & 1.566677 & 0.1277 \\
\hline TYPECREDIT & 0.405861 & 0.230464 & 1.761064 & 0.0884 \\
\hline DEGRERAT & 0.208043 & 0.173625 & 1.198231 & 0.2402 \\
\hline R-squared & 0.324009 & \multicolumn{2}{|c|}{ Meandependent var } & 0.325000 \\
\hline Adjusted R-squared & 0.121212 & \multicolumn{2}{|c|}{ S.D. dependent var } & 0.474342 \\
\hline S.E. of regression & 0.444666 & \multicolumn{2}{|c|}{ Akaike info criterion } & 1.429329 \\
\hline Sumsquaredresid & 5.931822 & \multicolumn{2}{|c|}{ Schwarz criterion } & 1.851549 \\
\hline Log likelihood & -18.58658 & \multicolumn{2}{|c|}{ Hannan-Quinn criter. } & 1.581990 \\
\hline Durbin-Watson stat & 1.860989 & & & \\
\hline
\end{tabular}

ANNEX. III. Elimination of THE VARIAbLE AGE AND the RE-ESTimation OF THE EQUATION

\begin{tabular}{|c|c|c|c|c|}
\hline \multicolumn{5}{|c|}{ Dependent Variable: RISQCREDIT } \\
\hline \multicolumn{5}{|l|}{ Method: Least Squares } \\
\hline \multicolumn{5}{|c|}{ Date: 29/07/19 Time: $21: 20$} \\
\hline \multicolumn{5}{|l|}{ Sample: 140} \\
\hline \multicolumn{5}{|c|}{ Included observations: 40} \\
\hline Variable & Coefficient & Std. Error & t-Statistic & Prob. \\
\hline SEXE & 0.122524 & 0.149736 & 0.818267 & 0.4195 \\
\hline MILIEUDERES & 0.103856 & 0.193859 & 0.535730 & 0.5960 \\
\hline ZONEGEO & 0.066633 & 0.052470 & 1.269930 & 0.2136 \\
\hline CSP & 0.096744 & 0.056629 & 1.708374 & 0.0976 \\
\hline NBREDOSCRED & -0.030639 & 0.103322 & -0.296544 & 0.7688 \\
\hline MONTCREDSOLLI & -0.273460 & 0.114625 & -2.385691 & 0.0233 \\
\hline DUREEREM & 0.222274 & 0.135152 & 1.644624 & 0.1102 \\
\hline TYPECREDIT & 0.395921 & 0.224624 & 1.762591 & 0.0878 \\
\hline DEGRERAT & 0.190603 & 0.160905 & 1.184570 & 0.2452 \\
\hline R-squared & 0.322034 & \multicolumn{2}{|c|}{ Meandependent var } & 0.325000 \\
\hline Adjusted R-squared & 0.147075 & \multicolumn{2}{|c|}{ S.D. dependent var } & 0.474342 \\
\hline S.E. of regression & 0.438073 & \multicolumn{2}{|c|}{ Akaike info criterion } & 1.382246 \\
\hline Sumsquaredresid & 5.949152 & \multicolumn{2}{|c|}{ Schwarz criterion } & 1.762244 \\
\hline Log likelihood & -18.64493 & \multicolumn{2}{|c|}{ Hannan-Quinn criter. } & 1.519642 \\
\hline Durbin-Watson stat & 1.861077 & & & \\
\hline
\end{tabular}


ANNEX. IV. ELIMINATION OF THE VARIABLE NUMBER OF CREDIT FILES AND THERE-ESTIMATION OF THE EQUATION

\begin{tabular}{|c|c|c|c|c|}
\hline \multicolumn{5}{|c|}{ DependentVariable: RISQCREDIT } \\
\hline \multicolumn{5}{|l|}{ Method: Least Squares } \\
\hline \multicolumn{5}{|c|}{ Date: 07/29/19 Time: 21:27 } \\
\hline \multicolumn{5}{|l|}{ Sample: 140} \\
\hline \multicolumn{5}{|c|}{ Included observations: 40} \\
\hline Variable & Coefficient & Std. Error & t-Statistic & Prob. \\
\hline SEXE & 0.126886 & 0.146873 & 0.863918 & 0.3941 \\
\hline MILIEUDERES & 0.116494 & 0.186402 & 0.624960 & 0.5364 \\
\hline ZONEGEO & 0.067668 & 0.051603 & 1.311329 & 0.1991 \\
\hline CSP & 0.094739 & 0.055417 & 1.709561 & 0.0970 \\
\hline MONTCREDSOLLI & -0.274303 & 0.112945 & -2.428643 & 0.0210 \\
\hline DUREEREM & 0.214715 & 0.130821 & 1.641287 & 0.1105 \\
\hline TYPECREDIT & 0.415985 & 0.211118 & 1.970389 & 0.0575 \\
\hline DEGRERAT & 0.177909 & 0.152880 & 1.163717 & 0.2531 \\
\hline R-squared & 0.320111 & \multicolumn{2}{|c|}{ Meandependent var } & 0.325000 \\
\hline Adjusted R-squared & 0.171385 & \multicolumn{2}{|c|}{ S.D. dependent var } & 0.474342 \\
\hline S.E. of regression & 0.431785 & \multicolumn{2}{|c|}{ Akaike info criterion } & 1.335079 \\
\hline Sumsquaredresid & 5.966028 & \multicolumn{2}{|c|}{ Schwarz criterion } & 1.672855 \\
\hline Log likelihood & -18.70158 & \multicolumn{2}{|c|}{ Hannan-Quinn criter. } & 1.457208 \\
\hline Durbin-Watson stat & 1.846679 & & & \\
\hline
\end{tabular}

ANNEX. V. Elimination of the VARIable Place of ResidenCE AND tHE RE-Estimation of the Equation

\begin{tabular}{|c|c|c|c|c|}
\hline \multicolumn{5}{|c|}{ DependentVariable: RISQCREDIT } \\
\hline \multicolumn{5}{|l|}{ Method: Least Squares } \\
\hline \multicolumn{5}{|c|}{ Date: $29 / 07 / 19$ Time: $21: 34$} \\
\hline \multicolumn{5}{|l|}{ Sample: 140} \\
\hline \multicolumn{5}{|c|}{ Includedobservations: 40} \\
\hline Variable & Coefficient & Std. Error & $\mathrm{t}$-Statistic & Prob. \\
\hline SEXE & 0.134660 & 0.144987 & 0.928771 & 0.3598 \\
\hline ZONEGEO & 0.069575 & 0.051034 & 1.363297 & 0.1820 \\
\hline CSP & 0.107824 & 0.050834 & 2.121104 & 0.0415 \\
\hline MONTCREDSOLLI & -0.308620 & 0.097783 & -3.156157 & 0.0034 \\
\hline DUREEREM & 0.248393 & 0.118100 & 2.103230 & 0.0432 \\
\hline TYPECREDIT & 0.438383 & 0.206123 & 2.126799 & 0.0410 \\
\hline DEGRERAT & 0.184605 & 0.151089 & 1.221827 & 0.2304 \\
\hline R-squared & 0.311812 & \multicolumn{2}{|c|}{ Meandependent var } & 0.325000 \\
\hline Adjusted R-squared & 0.186687 & \multicolumn{2}{|c|}{ S.D. dependent var } & 0.474342 \\
\hline S.E. of regression & 0.427780 & \multicolumn{2}{|c|}{ Akaike info criterion } & 1.297211 \\
\hline Sumsquaredresid & 6.038847 & \multicolumn{2}{|c|}{ Schwarz criterion } & 1.592765 \\
\hline Log likelihood & -18.94421 & \multicolumn{2}{|c|}{ Hannan-Quinn criter. } & 1.404074 \\
\hline Durbin-Watson stat & 1.899551 & & & \\
\hline
\end{tabular}


ANNEX. VI. ELIMINATION OF THE VARIABLE GENDER AND THE RE-ESTIMATION OF THE EQUATION

\begin{tabular}{|c|c|c|c|c|}
\hline \multicolumn{5}{|c|}{ DependentVariable: RISQCREDIT } \\
\hline \multicolumn{5}{|l|}{ Method: Least Squares } \\
\hline \multicolumn{5}{|c|}{ Date: 07/29/19 Time: 21:38 } \\
\hline \multicolumn{5}{|l|}{ Sample: 140} \\
\hline \multicolumn{5}{|c|}{ Includedobservations: 40} \\
\hline Variable & Coefficient & Std. Error & t-Statistic & Prob. \\
\hline ZONEGEO & 0.073479 & 0.050758 & 1.447632 & 0.1569 \\
\hline CSP & 0.116151 & 0.049936 & 2.326006 & 0.0261 \\
\hline MONTCREDSOLLI & -0.337580 & 0.092491 & -3.649873 & 0.0009 \\
\hline DUREEREM & 0.294141 & 0.107121 & 2.745872 & 0.0096 \\
\hline TYPECREDIT & 0.467207 & 0.203362 & 2.297416 & 0.0279 \\
\hline DEGRERAT & 0.190543 & 0.150649 & 1.264817 & 0.2145 \\
\hline R-squared & 0.293823 & \multicolumn{2}{|c|}{ Meandependent var } & 0.325000 \\
\hline Adjusted R-squared & 0.189974 & \multicolumn{2}{|c|}{ S.D. dependent var } & 0.474342 \\
\hline S.E. of regression & 0.426914 & \multicolumn{2}{|c|}{ Akaike info criterion } & 1.273015 \\
\hline Sumsquaredresid & 6.196701 & \multicolumn{2}{|c|}{ Schwarz criterion } & 1.526347 \\
\hline Log likelihood & -19.46029 & \multicolumn{2}{|c|}{ Hannan-Quinn criter. } & 1.364612 \\
\hline Durbin-Watson stat & 1.773236 & & & \\
\hline
\end{tabular}

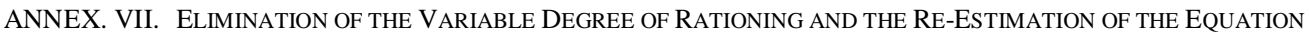

\begin{tabular}{|c|c|c|c|c|}
\hline \multicolumn{5}{|c|}{ DependentVariable: RISQCREDIT } \\
\hline \multicolumn{5}{|l|}{ Method: Least Squares } \\
\hline \multicolumn{5}{|c|}{ Date: 07/29/19 Time: $21: 42$} \\
\hline \multicolumn{5}{|l|}{ Sample: 140} \\
\hline \multicolumn{5}{|c|}{ Included observations: 40} \\
\hline Variable & Coefficient & Std. Error & t-Statistic & Prob. \\
\hline ZONEGEO & 0.074019 & 0.051189 & 1.445979 & 0.1571 \\
\hline CSP & 0.116358 & 0.050361 & 2.310457 & 0.0269 \\
\hline MONTCREDSOLLI & -0.364881 & 0.090704 & -4.022743 & 0.0003 \\
\hline DUREEREM & 0.347684 & 0.099241 & 3.503426 & 0.0013 \\
\hline TYPECREDIT & 0.491187 & 0.204203 & 2.405380 & 0.0216 \\
\hline R-squared & 0.260596 & \multicolumn{2}{|c|}{ Meandependent var } & 0.325000 \\
\hline Adjusted R-squared & 0.176093 & \multicolumn{2}{|c|}{ S.D. dependent var } & 0.474342 \\
\hline S.E. of regression & 0.430557 & \multicolumn{2}{|c|}{ Akaike info criterion } & 1.268993 \\
\hline Sumsquaredresid & 6.488267 & \multicolumn{2}{|c|}{ Schwarz criterion } & 1.480103 \\
\hline Log likelihood & -20.37986 & \multicolumn{2}{|c|}{ Hannan-Quinn criter. } & 1.345324 \\
\hline Durbin-Watson stat & 1.779325 & & & \\
\hline
\end{tabular}

